\title{
Expanding the journey of saving lives
}

\author{
Clive Callender ${ }^{1 *}$ and Patrice V Miles ${ }^{2}$ \\ ${ }^{1}$ Department of Surgery, Howard University College of Medicine, USA \\ ${ }^{2}$ National Minority Organ Tissue Transplant Education Program (MOTTEP), USA
}

\begin{abstract}
A shortage of donors is the number one problem in transplantation. In 1982, minorities represented more than $50 \%$ of the national waiting list but composed only $15 \%$ of donors. Blacks, comprising only $3 \%$ of donors, were thought of as non-donors.

Due to the lack of transplant awareness, Black participants were reluctant to become donors. The methods we used to address the reluctance were based on community grassroots, face-to-face interactions from 1982 to 1988 that focused on increasing African-American donation rates. From 1982 to 1988 , African American donor card signings increased from 20 per month to 750 per month and African American donations doubled in the Washington, D.C. area. After a nationwide Blackfocused media campaign, Gallup Polls (1985 vs. 1990) indicated a tripling of transplant awareness and signed donor cards among Black participants. Based upon the above methods, the National Minority Organ Tissues Transplant Education Program was established in 1991 targeting ethnic minority groups, thus expanding the journey of saving lives through organ donation to include all minority populations. Data from the United Network for Organ Sharing (UNOS) database from 1990 to 2017 were analyzed to determine if there was an increase in minority donors.
\end{abstract}

Nationally, African American and Latino/Hispanic organ donors per million (ODM) increased from 8 to 10 ODM in 1982 to 30 ODM in 2002. National minority donor percentages increased from $15 \%$ to $28.5 \%$ in 2002 (minorities composed $25 \%$ of the USA population in 2000).

Based upon the 2010 UNOS data, Black participants ranked highest in ODM within the US, indicating that, when utilizing face-to-face presentations/interactions combined with multimedia, donation rates can be increased and sustained. Therefore, these approaches can positively impact donation rates in all communities. The increase in 2010 (32 years and 4 decades later) is significant as the Black population became the ethnic group with the highest ODM rate of 35 ODM in 2010 and 38 ODM in 2017 in the USA. This makes expanding the MOTTEP model to all ethnic groups an important next step in increasing donations.

\section{Aim}

This manuscript identifies the successful strategies used to overcome and sustain organ donation efforts in the African American population and when funding is sufficient, are applicable to all ethnic groups.

In 1978, the Southeastern Organ Procurement Foundation (SEOPF) reported to us a striking disparity in the Southeastern part of the US, where Blacks made up $70 \%$ of the patients on dialysis, but less than $10 \%$ of the donors for transplantation. Unfortunately, while the SEOPF acknowledged this problem, they reported a lack of funds to help in its solution [1]

This author, along with Dr. James Bayton and his team, recognized the importance of this problem and sought to identify the reasons for the Black donor reluctance. A pilot study funded by Howard University was organized to identify the reasons for this Black donor unwillingness. We interviewed 40 African Americans from the District of Columbia and were able to simultaneously: 1 ) identify the 5 obstacles to donation and 2) identify the modus operando's to successfully overcome this Black donor reluctance [1-4].

Five Obstacles to Donation

Lack of transplant awareness

Religious myths and misperceptions

Medical distrust

Fear of premature death

Racism (Figure 1)
During the study, respondents opined that Black participants were unlikely to donate organs and the task of getting Black participants to donate was difficult. At that time Black participants composed 3\% of US donors and had an organ donor per million (ODM) rate of 8 ODM [1-3]. By 2010, despite the earlier data, this same group reported the highest ODM rate in the US (through 2017) as noted in Tables 1 and 2 [4-6].

\section{Methods}

Since 1982, we have been involved with a grassroots effort emphasizing community education and empowerment. This effort emphasizes the use of ethnically similar and culturally sensitive messengers who are donors, with both their families and transplant recipients, along with healthcare providers, taking an ethnically appropriate message to their communities. The communities then accept and take the message by their own organized methods and further educates and empowers members to sign donor cards, have family discussions, and leave organs to others in need after the death of the donor [1-3,5].

From 1982 to 1988, this community education method was taken to the Washington, D.C. metropolitan area by the D.C. Organ Donor

${ }^{\star}$ Correspondence to: Clive Callender, Professor of Surgery, Howard University College of Medicine, USA, E-mail: ccallender@Howard.edu

Received: February 12, 2019; Accepted: March 04, 2019; Published: March 08, 2019 

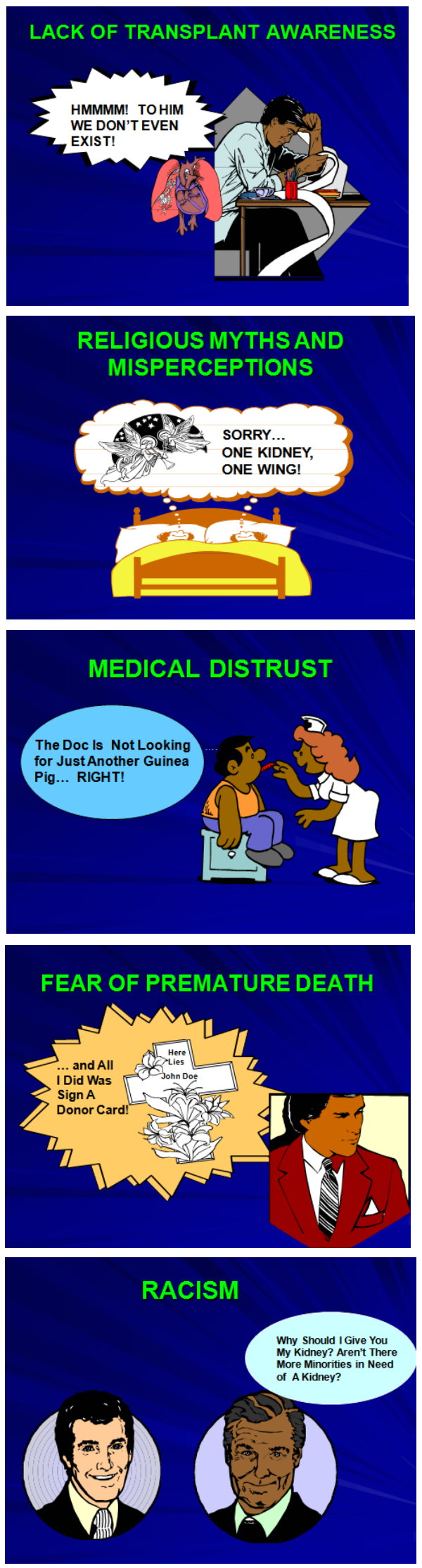

Figure 1. Obstacles to donation
Program (a partnership between the National Kidney Foundation and Howard University) and resulted in the D.C. metropolitan area increasing the number of donor cards signed on drivers licenses from 25 signed per month in 1982 to 700 cards signed per month in 1988 , and doubled the number of Black donors in the area between 1983 and 1994 (12 and 26, respectively).

Because of these program-driven donor increases in the District of Columbia, the Dow Chemical Company created the Dow Chemical Company Take Initiative Program, a multimedia program that was taken to 14 cities with the highest Black population using radio, television, newspaper, and Black magazines to reach a potential audience of 50 million African Americans. Simultaneously, the Dow Take Initiative was taken to 4 Historically Black Colleges and Universities and the National Association for the Advancement of Colored People (NAACP). The results of the Dow Take Initiative Donor Awareness Program were: 10 million consumer impressions generated; 40,000 students and faculty reached; 200 students signed organ donor cards at North Carolina A\&T and 1,200 students completed student surveys [6-13].

As a consequence of these African American donor programs, data from the Dow Chemical Gallup poll surveys taken in 1986 and 1991, showed that African American awareness of the highly successful nature of transplantation rose from $7 \%$ in 1986 to $24 \%$ in 1990; in addition the percentage of signed African-American donor cards rose from $10 \%$ to $31 \%$ in 1990 . In Washington D.C. the organ donor consent rates rose from $10 \%$ in 1978 to $51 \%$ in 1993 . Nationally, the ODM number rose from 8 ODM in 1982 to 20 ODM in 1992, and the percentage of African American donors rose from 3\% in 1982 to $11.6 \%$ in 1993 [14].

Given the promising results of these programs [1-3,5-14] and the primary author's involvement in each of the aforementioned programs, The National Minority Organ Tissue Transplant Education Program (MOTTEP) was conceptualized in 1991 and first presented at The Surgeon General's Workshop on Increasing Organ Donation in 1991 [3]. The goal of National MOTTEP was to take the successful strategies of the African American programs named above to increase organ and tissue donation and expand them to other minority groups (Latinos/ Hispanics, Asians, American Indians, and Alaska Natives).

National MOTTEP's mission is to decrease the rate and number of ethnic minority Americans needing organ and tissue transplants [14-17]. This mission is especially important since minorities suffer disproportionately with uncontrolled high blood pressure and diabetesthe two leading causes of kidney failure [18-20].

MOTTEP's prevention and intervention strategies were then applied nationally to: increase the number of ethnic minorities who are knowledgeable about donation and transplantation; increase the number of minority families who have discussions about donation; increase the number of ethnic minorities willing to donate their organs and tissues; and increase the number of ethnic minorities who adopt healthier lifestyles and behavior patterns thereby decreasing the need for transplantation $[14,18,19]$.

From 1993 to 2008, the National Institutes of Health provided grant funds allowing National MOTTEP to develop 15 MOTTEP sites across the United States for community education and empowerment to each of the 5 ethnic minority groups. During this period, National MOTTEP was able to make significant strides. National MOTTEP was the first to: 1) implement the National Minority Transplant Strategic Plan in 1995; 2) identify the community as the most potent and cost efficient change agent from 1993 to 1995 ; 3) emphasize the importance of preventing 
Table 1. Organ donors per million, 1999-2010 [24]

\begin{tabular}{|c|c|c|c|c|c|c|c|c|c|c|c|c|}
\hline \multirow[b]{2}{*}{ Year } & \multicolumn{3}{|c|}{ White } & \multicolumn{3}{|c|}{ Black } & \multicolumn{3}{|c|}{ Hispanic } & \multicolumn{3}{|c|}{ Asian } \\
\hline & \#Donors & Population & $\begin{array}{l}\text { Doners } \\
\text { PMP }\end{array}$ & \# Donors & Population & $\begin{array}{c}\text { Doners } \\
\text { PMP }\end{array}$ & \# Donors & Population & $\begin{array}{c}\text { Doners } \\
\text { PMP }\end{array}$ & \# Donors & Population & $\begin{array}{c}\text { Doners } \\
\text { PMP }\end{array}$ \\
\hline 1999 & 6,835 & 226,861 & 30.13 & 959 & 35,470 & 27.04 & 1,010 & 32,832 & 30.76 & 176 & 11,279 & 15.60 \\
\hline 2000 & 6,978 & 224,611 & 31.07 & 932 & 34,862 & 26.73 & 992 & 31,337 & 31.66 & 194 & 10,820 & 17.93 \\
\hline 2001 & 7,128 & 230,290 & 30.95 & 1,043 & 36,247 & 28.77 & 1,082 & 36,972 & 29.27 & 183 & 10,983 & 16.66 \\
\hline 2002 & 7,070 & 232,647 & 30.39 & 1,129 & 36,746 & 30.72 & 1,138 & 38,222 & 29.77 & 176 & 11,559 & 15.23 \\
\hline 2003 & 7,018 & 234,241 & 29.96 & 1,140 & 37,082 & 30.74 & 1,215 & 39,373 & 30.86 & 201 & 11,933 & 16.84 \\
\hline 2004 & 7,165 & 236,064 & 30.35 & 1,195 & 37,496 & 31.87 & 1,306 & 40,754 & 32.05 & 230 & 12,321 & 18.67 \\
\hline 2005 & 7,177 & 237,855 & 30.17 & 1,300 & 37,909 & 34.29 & 1,416 & 42,082 & 33.65 & 200 & 12,687 & 15.76 \\
\hline 2006 & 7,354 & 239,746 & 30.67 & 1,392 & 38,343 & 36.30 & 1,482 & 43,693 & 33.92 & 221 & 13,159 & 16.79 \\
\hline 2007 & 7,126 & 241,167 & 29.55 & 1,294 & 38,756 & 33.39 & 1,493 & 44,853 & 33.29 & 216 & 13,366 & 16.16 \\
\hline 2008 & 6,970 & 242,639 & 28.73 & 1,308 & 39,059 & 33.49 & 1,422 & 46,228 & 30.76 & 241 & 13,549 & 17.79 \\
\hline 2009 & 6,689 & 244,298 & 27.38 & 1,316 & 39,641 & 33.20 & 1,385 & 47,655 & 29.06 & 235 & 14,014 & 16.77 \\
\hline 2010 & 6,558 & 242,295 & 27.07 & 1,427 & 40,358 & 35.36 & 1,300 & 50,810 & 25.59 & 224 & 15,239 & 14.70 \\
\hline
\end{tabular}

Table 2. Results of telephone interviews pre- and post-intervention surveys: Adult survey results [21]

\begin{tabular}{|c|c|c|c|}
\hline Metric & Signed Donor Cards (\%) & Held Family Discussions (\%) & Willingness to Donate (\%) \\
\hline Follow-up & 56.8 & 62.0 & 81.0 \\
\hline Post Survey & 83.0 & 82.0 (will hold) \\
\hline Pre-Survey & 37.3 & 37.0 & 68.0 \\
\hline
\end{tabular}

the need for transplantation and increasing the number of organ/tissue donors as the most efficient mode of community transplant outreach; 4) conceptualize and inaugurate National Minority Donor Awareness Day (August 1, 1996; now known as National Minority Donor Awareness Week); 5) develop the "Triple A Effect," emphasizing moving communities from Awareness to Action and Accountability in 2009; 6) develop the "Love Yourself, Take Care of Yourself Campaign" in 2001 [14-17]; 7) develop and utilize pre-intervention and post-intervention survey questionnaires as tools for donor program evaluations in 1995; and 8) utilize Telehealth as an effective tool to help individuals better manage diabetes and improve health behaviors to "Prevent the Need" and reinforce the Triple-A Effect [20].

National MOTTEP developed a comprehensive evaluation model and quantitative and qualitative survey tools to gauge the effectiveness of its programs. Its initial evaluation model was developed to measure the national program on the participant level, program level, and community level. After that, the evaluation tools using pre-program and post-program questionnaires were developed to measure the community responses regarding knowledge, attitudes, beliefs, health practices, and action intentions (i.e., "Will I sign a donor card and/or change my health behaviors?”) [14] (Figure 2).

The National MOTTEP evaluation model allowed for meaningful participant feedback allowing for an independent analysis of 10,000 matched data sets (Table 2) [21] (Figure 3).

\section{Results}

The results of these analyses indicated that culturally appropriate health programs designed for a targeted population could change attitudes, beliefs, and behavioral intentions.

From 1995 to 2010, minority donation percentages increased from $15 \%$ to $31 \%$. African American ODM increased from 8 ODM in 1982 to 32 ODM in 2010, and White and Latino/Hispanic donor rates dropped between 2000 and 2010 [22].

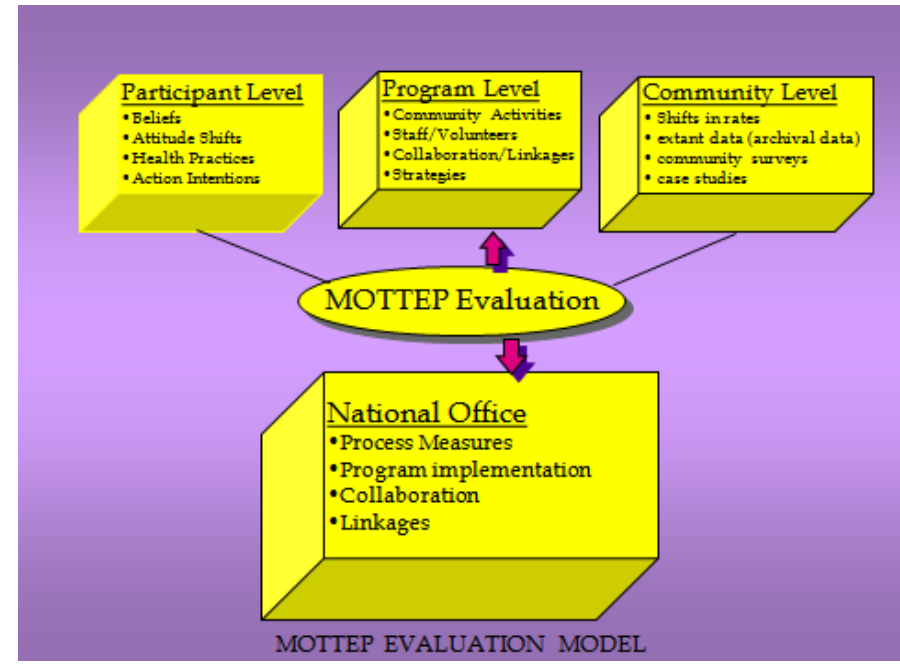

Figure 2. MOTTEP evaluation model

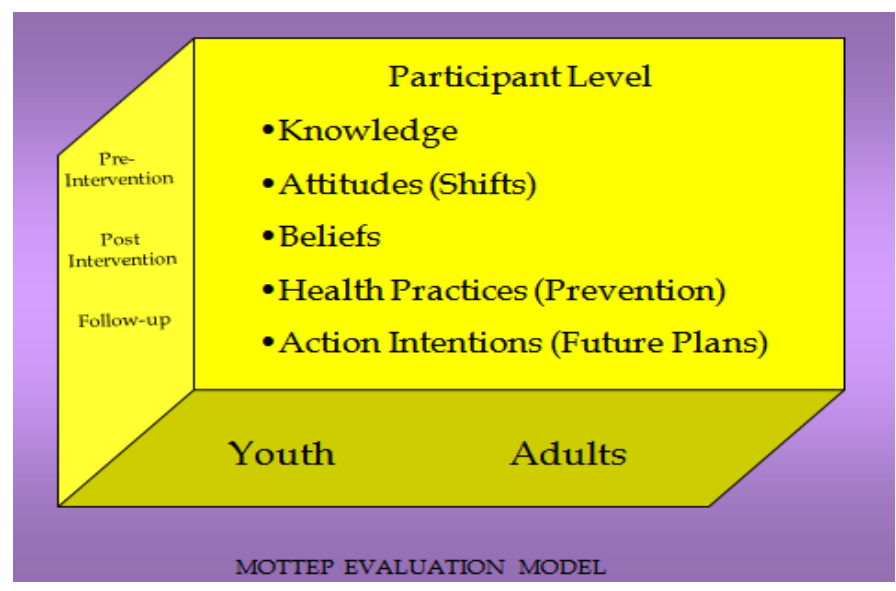

Figure 3. MOTTEP evaluation model 
In 1995, ODM was 34 for Whites, 33 for Blacks, 31 for Hispanic, and 17 for Asian. In 2010, Black ODM totaled 35 versus 27 for Whites, 26 for Hispanic and 15 for Asian. Then, Black participants represented $17 \%$ of the donor population and $13 \%$ of the total U.S. population (Table 3) [22].

\section{In 2017 (Table 4) Black ODM rates increased to 38 ODM (24).}

The data in Table 4 [14] indicate a higher donation rate in Organ Procurement Organization service areas with a MOTTEP presence versus those areas without a MOTTEP presence. Table 5 illustrates the increase in donors, donation rates, and ODM. From 1990 to 2008 , minority donations percentages doubled (from $15 \%$ to $30 \%$, respectively). Of special note, Tables 5 and 6 [14] quantifies the success of the only national minority public education program of its kind in the world [14].

\section{Discussion}

The United Network for Organ Sharing (UNOS) data from 2000 to 2017 suggests community education and empowerment, when combined with multimedia reinforcement, can increase and sustain Black organ donation rates [22,23]. This has occurred despite concurrent declining White and Latino/Hispanic donation rates for the same period. The increase of Black ODM and the Black ethnic group's rise from the bottom to the top in organ donation rates may reflect the importance of sustaining the face-to-face grassroots community education and empowerment effort.

The community-driven efforts within the Black community are a consequence of a grassroots face-to-face effort which optimizes the MOTTEP methods [1-3,5-19]. This grassroots strategy has the

Table 3. UNOS/OPTN-Organ donors per million comparisons (1995 versus 2010) [22]

\begin{tabular}{|c|c|c|c|c|}
\hline Year & Blacks & Whites & Hispanics & Asians \\
\hline 1995 & 33.1 & 34.2 & 31.5 & 17.9 \\
\hline 2010 & 35.36 & 27.07 & 25.59 & 14.70 \\
\hline
\end{tabular}

Table 4. MOTTEP versus Non MOTTEP cities* [14]

\begin{tabular}{|c|c|c|c|c|c|}
\hline \multirow[b]{2}{*}{ Ethnicity } & \multicolumn{2}{|c|}{ MOTTEP } & \multicolumn{2}{|c|}{ Non MOTTEP } & \multirow[b]{2}{*}{$p$-value } \\
\hline & $\begin{array}{c}\text { Donation } \\
\text { Rate }\end{array}$ & Donors & $\begin{array}{c}\text { Donation } \\
\text { Rate }\end{array}$ & Donors & \\
\hline White, Non-Hispanic & 59.3 & 4,928 & 59.2 & 11,279 & 0.02 \\
\hline White, Hispanic & 106.9 & 1,055 & 47.4 & 886 & $<.01$ \\
\hline Black & 43.4 & 1,263 & 32.9 & 1,286 & $<.01$ \\
\hline Other & 50.7 & 228 & 42.4 & 272 & $<.01$ \\
\hline
\end{tabular}

"Cadaveric donors per 1,000 evaluable deaths and number of donors by ethnicity and Organ Procurement Organizations from 1995-1998

Table 5. Ethnicity-based organ donors per million. Data: Organ procurement and transplant network [23]

\begin{tabular}{|c|c|c|c|c|}
\hline Year & Black & White & Hispanic & Asian \\
\hline 1995 & 33.1 & 34.2 & 31.5 & 17.9 \\
\hline 2010 & 35.36 & 27.07 & 25.59 & 14.7 \\
\hline 2017 & 38.1 & 34.29 & 27.5 & 15.1 \\
\hline
\end{tabular}

Table 6. Black population organ donors 1988-2018. Data: Organ procurement and transplant network [23]

\begin{tabular}{|c|c|c|c|}
\hline Year & $\begin{array}{c}\text { Black deceased } \\
\text { donation }\end{array}$ & $\begin{array}{c}\text { Total deceased } \\
\text { donation }\end{array}$ & Percentage \\
\hline 1988 & 359 & 4080 & $8.8 \%$ \\
\hline 1998 & 646 & 5793 & $11.2 \%$ \\
\hline 2008 & 1276 & 7989 & $16.0 \%$ \\
\hline 2017 & 1603 & 10,287 & $15.6 \%$ \\
\hline
\end{tabular}

potential for adaptability to all ethnic groups. Since Latino/Hispanic and White ethnic groups have declined in their ODM, we suggest the application of this methodology to all ethnic groups. We believe the use of social media efforts are mandatory, but not to the exclusion of grassroots, face-to-face efforts which may generate the trust that other efforts may not be able to duplicate. In addition, approximately $13 \%$ of the U.S. population is not computer literate. (41\% over $65,16 \%$ African Americans and Hispanics) [24].

National MOTTEP's role in the donation increase can be attributed to the aggressive nature of the MOTTEP sites in increasing donation awareness and donor registrations. The impact of several MOTTEP sites is described below $[14,22,24]$.

\section{Honolulu, $\mathrm{HI}$}

Since its implementation in 1995, MOTTEP of Honolulu primarily targeted the Filipino community. Within the first 3 to 4 years, the program's success is noted the increase in the Filipino donor consent from $3 \%$ to $27 \%$. Over the past several years, organ donation consent rates among Filipinos have steadily increased (40\% in 2004, 67\% in 2005 , and $71 \%$ in 2006). The result of this successful program is evidenced in increased donor consent in the Filipino community from $3 \%$ to $71 \%[14]$.

\section{Detroit, MI}

MOTTEP of Detroit participates in more than 400 communitybased activities each year and has tripled donation rates within the Detroit area from 5\% when MOTTEP began activities. MOTTEP of Detroit is one of several sites to utilize technology to increase the number of potential donors through the statewide registry. The African American consent rates rose from $40.91 \%$ in 2008 to $54.11 \%$ in 2009 , to $64.79 \%$ in 2010 [14].

\section{New York, NY}

MOTTEP of New York has an effective community outreach strategy based on its partnership with Voter Registration. When New York became a MOTTEP site in 1995, the donation rate was below $50 \%$. As of 2015 , the donation rate is $61 \%$. More than 100 new persons (on average) have registered to be donors each week over the last year. The voter registration campaign has made this MOTTEP of New York's greatest accomplishment as it has registered thousands of New Yorkers as voters and organ donors [22]. In addition to all the community work on the ground in the local sites, National MOTTEP actively seeks to publish research findings, data, and community strategies. The overall goal is to publish the effectiveness of community outreach and education as a modus operandi to effectively reach the community at a grassroots level and assist members of the community in becoming "changeagents" who can help solve the number one problem in transplantation, i.e., the shortage of donors, while simultaneously decreasing the high incidence of renal disease.

The National MOTTEP model has been successful because it takes its education program directly to the targeted audiences. MOTTEP seeks to utilize natural communication systems that exist within each targeted minority group's community to disseminate information about organ donation and transplantation and to educate audiences regarding the need to hold family discussions not only about organ/tissue donation but family medical history and health practices in general.

\section{Conclusion}

When a campaign composed of face-to-face interactions is combined with a multimedia campaign, donation rates can be increased 
and sustained. Obtaining adequate funding for the current MOTTEP sites and expanding their scope, along with adding 7 additional sites targeting all ethnic groups (thus expanding our journey to save lives) can contribute to an increased significant impact on organ donation rates.

To address the number one problem in transplantation today, more programs are needed to increase the number of organ donors and decrease the number of persons being added to waiting lists. The National MOTTEP believes that aggressive community outreach to all ethnic groups using its grassroots and face-to-face strategy along with media and social media efforts are the answer to increasing organ donation rates.

\section{References}

1. Callender CO, Bayton JA, Yeager CL, Clark JE (1982) Attitudes among blacks toward donating kidneys for transplantation: A pilot project. J Natl Med Assoc 74: 807-809. [Crossref]

2. Callender CO (1989) The results of transplantation in blacks: just the tip of the iceberg. Transplant Proc 21: 3407-3410. [Crossref]

3. Callender CO (1991) Organ/tissue donation in African Americans: a national stratagem. The surgeon general's workshop on increasing organ donation: Proceedings. Novello AC (ed.): US department of health and human services, public health service, office of the surgeon general of the United States, Washington, DC, 1: 145-162.

4. UNOS/OPTN database. Accessed March 26, 2015. https://optn.transplant.hrsa.gov/ data/view-data-reports/national-data/.

5. Callendar CO, Hall LE, Yeager CL, Barber JB Jr, Dunston GM, et al. (1991) Organ donation and blacks. A critical frontier. $N$ Engl J Med 325: 442-444. [Crossref]

6. Hall LE, Callender CO, Yeager CL, Barber JB, Dunston GM, et al. (1991) Organ donation and blacks: The next frontier. Transplant Proc 23: 2500-2504. [Crossref]

7. Reitz N, Callender CO (1993) Organ donation in the African American population: A fresh perspective with a simple solution. J Natl Med Assoc 85: 353-358. [Crossref]

8. Callender CO, Hall LE, Yeager CL, Washington AW, Grace Smith P (1994) Anatomy of a community-based transplant education program: A model for community empowerment. It Just Ain't Fair. Dula A, Goering S (eds): Praeger, Westport, CN, pp: 235-243.

9. Callender CO (1994) ESRD and transplantation in minorities: A proposed national transplant strategy based on community education and empowerment. Contemp Dial Nephrol 15: 23-25.
10. Callender CO, Bey AS, Miles PV, Yeager CL (1995) A national minority organ/tissue transplant education program: the first step in the evolution of a national minority strategy and minority transplant equity in the USA. Transplant Proc 27: 1441-1443.

11. Callender CO, Burston BW, Burton LW, Miles PV (1996) An assessment of the impact of the national minority organ/tissue transplant education program (MOTTEP). Transplant Proc 28: 394-397.

12. Callender CO, Burston B, Yeager C, Miles P (1997) A national minority transplant program for increasing donation rates. Transplant Proc 29: 1482-1483.

13. Miles P, Callender CO (1997) Community education and empowerment key to increased minority donation rates. Transplant Proc 29: 3756-3757.

14. Callender CO, Miles PV (2010) Minority organ donation: the power of an educated community. J Am Coll Surg 210: 708-715, 715-717. [Crossref]

15. Callender CO, Hall MB (2001) Dilemma of organ and tissue transplantation. Health issues in the black community. Braithwaite R (ed): Jossey Bass, California, 9: 167-185.

16. Callender CO, Hall MB, Branch D (2001) An assessment of the effectiveness of the MOTTEP model for increasing donation rates and preventing the need for transplantation-adult findings: Program years 1998 and 1999. Semin Nephrol 21: 419428. [Crossref]

17. Callender CO, Miles PV, Hall MB (2002) National MOTTEP: Educating to prevent the need for transplantation. Minority organ tissue transplant education program. Ethn Dis 12: S1-34-37. [Crossref]

18. Callender CO, Miles PV, Hall MB (2002) Increasing living donations: Expanding the national MOTTEP community grass root model. Transplant Proc 34: 2563-2564. [Crossref]

19. Callender CO, Maddox G (2004) Three decades overcoming the African-American donation disparity. Nephrol News Issues 18: 39-40,57.

20. Carter EL, Nunlee-Bland G, Callender C (2011) A patient-centric, provider-assisted diabetes telehealth self-management intervention for urban minorities. Perspect Health Inf Manag 8: 1b. [Crossref]

21. Callender CO, Miles PV, Hall MB (2003) Experience with national minority organ tissue transplant education program in the United States. Transplant Proc 35: 1151 1152.

22. Callender CO, Koizumi, N, Miles, PV, Melancon, JK (2016) Organ donation in the United States: the tail of the African American journey of moving from the bottom to the top. Transplant Proc 48: 2392-2395. [Crossref]

23. Chugh N (2018) Organ donation, breaking taboos amongst British BAME communities. Winston Churchill Memorial Trust, pp: 14-18. wcmt.org.uk.

24. 13\% of Americans don't use the internet. Who are they? Accessed September 7, 2016 http://www.pewresearch.org/fact-tank/2016/09/07/some-americans-dont-use-theinternet-who-are-they/.

Copyright: (C2019 Callender C. This is an open-access article distributed under the terms of the Creative Commons Attribution License, which permits unrestricted use, distribution, and reproduction in any medium, provided the original author and source are credited. 